\title{
EL CUERPO DE LA NACIÓN: ALEGORÍAS Y SÍMBOLOS POLÍTICOS EN LA ESPAÑA LIBERAL (1808-1874)
}

\author{
MARIE-ANGÈLE OROBON \\ Université Sorbonne Nouvelle - Paris 3
}

Recibido: 31/10/2010

Aceptado: 2/12/2010

\section{Resumen}

Partiendo de una reflexión en torno a la metáfora del cuerpo político en tanto que órgano de representación política, este artículo propone un acercamiento a la plasmación alegórica y simbólica del cuerpo de la nación como sujeto de imputación del poder en la época liberal. Si bien la Guerra de la Independencia hace emerger una alegoría femenina, emancipada de la monarquía, para encarnar a la nación como actor político, es el cuerpo de Isabel II, reina-niña, el que simboliza el afianzamiento del liberalismo en España. Finalmente, con la democratización de la política que, paradójicamente, consagra la desigualdad de la mujer, la figura femenina, entre alegoría y realidad, llega a cobrar en la imaginería política un protagonismo creciente hasta identificarse con el nuevo poder en gestación: el del pueblo.

Palabras clave: alegoría, género, nación, cuerpo político, simbología política, soberanía.

\begin{abstract}
Starting from a survey of the metaphor of the political body, this article offers an approach of the allegorical and symbolic embodiment of the nation as the character in charge of power in the liberal period. The War of Independence imposes the female allegory, emancipated from the monarchy as it
\end{abstract}


is, to embody the nation as the actor on the political stage. Whereas it is the actual body of Isabel II, both a little girl and a queen, which symbolizes the subsequent consolidation of liberalism in Spain. Finally, together with politics becoming democratic, which paradoxically establishes the unequal status of woman by making her a political outcast, the female figure plays an essential part in political imagery, halfway between allegory and reality, to the extent of being identified with the new power on the way: the power of the people.

Key Words: allegory, gender, nation, political body, political symbolism, sovereignty. 
Hace ya varios años el historiador francés Antoine de Baecque demostró, en un libro original y sugerente la importancia de las metáforas en historia. El cuerpo de la historia, así se titulaba la obra, trataba esencialmente, siguiendo el hilo de las formas corporales de la representación política en los años bisagra de la Revolución francesa, del traspaso de la soberanía del cuerpo del rey al gran cuerpo de los ciudadanos ${ }^{1}$.

El uso políticamente orientado de la metáfora corpórea para designar al titular del poder político -el cuerpo del rey, como símbolo encarnado del reino, el cuerpo de la nación como titular de la soberanía- procede de un tropo admitido de antiguo. Derivado del latín en que la palabra corpus designaba en sentido figurado una reunión de personas (como en el sintagma corpus civitatis), se difunde el sentido político de la metáfora corporal en la edad moderna bajo la influencia del espíritu humanista del Renacimiento, que hace del cuerpo humano medida de todas las cosas, estableciéndose correspondencias entre el universo (macrocosmos), el cuerpo humano (microcosmos) y el «cuerpo de la república», como trasunto de éste último². Mientras la formación de los Estados centralizados en el siglo XVI, apoyados en la monarquía de derecho divino, hace del rey la cabeza, el corazón o el alma del «cuerpo de la república» ${ }^{3}$, se asienta en Inglaterra, a finales de ese mismo siglo, la idea de soberanía del parlamento, compuesto por el príncipe y las dos cámaras. A ese «cuerpo político», como lo denominan Thomas Smith, en De Republica Anglorum y Richard Hooker, en Of the Laws of Ecclesiastical Politic, en tanto que órgano de representación individualista y no organicista, corresponde el poder de hacer las leyes ${ }^{4}$.

1. BAECQUe, Antoine de. Le corps de l'histoire. Métaphores et politique (1700-1800). París, Calmann-Lévy, 1993.

2. REDONDO, Augustin. «Introduction». En A. Redondo (ed.). Le corps comme métaphore dans l'Espagne des XVI et XVII siècles. Paris, Presses de la Sorbonne Nouvelle, 1992, p. 5.

3. Ibíd., p. 6.

4. VAREla SuAnZeS-CARPEGNA, Joaquín, «La soberanía en la doctrina británica (de Bracton a Dicey)». Fundamentos, 1 (1998), pp. 87-166. Quiero agradecer a los profesores Joaquín Varela Suanzes-Carpegna (de la Universidad de Oviedo) y Javier Fernández Sebastián (de la Universidad del País Vasco) su valiosa y amistosa ayuda.

Feminismo/s 16, diciembre 2010, pp. 39-64 
Un siglo más tarde, en An Essay Concerning the True Original Extent and End of Civil Government (1690), John Locke entiende por «cuerpo político» no al parlamento, sino a la comunidad formada por el consentimiento individual de los hombres que se han incorporado a dicha comunidad ${ }^{5}$. Así el filósofo inglés otorga al sintagma «cuerpo político» el sentido de individualidad (los hombres que forman la comunidad por consentimiento individual) y de unidad: se entiende que el cuerpo político así formado actúa como un solo cuerpo (one body), obligándose los hombres que han integrado este cuerpo político a someterse a la decisión de la mayoría ${ }^{6}$. El concepto de soberanía que va vinculado a la noción de «cuerpo político», sea éste la representación de una comunidad o esa misma comunidad, como aparece en los escritos de los publicistas ingleses, lo une Rousseau, en 1762, en su teoría del «contrato social», a la idea de «voluntad general» y el abate Sieyès, en su famoso opúsculo Qu'est-ce que le tiers-état? de enero de 1789, identifica la soberanía con la nación incorporada por el tercer estado. Para Sieyès la nación es «un corps d'associés vivant sous une loi commune et représentés par la même législature ${ }^{7}$ es decir, una misma asamblea encargada de legislar. Este escrito tendría decisiva influencia sobre la formación de la Asamblea Nacional, luego Asamblea Constituyente, a partir de la reunión de los États Généraux de mayo de 1789 en Versalles.

Apenas dos décadas más tarde, en España, las Cortes reunidas en Cádiz, culminando el impulso de resistencia popular contra la invasión napoleónica de 1808 que se había traducido políticamente en las juntas patrióticas, se declaran depositarias de la soberanía nacional. «Los diputados que componen este Congreso, y que representan a la nación española, se declaran legítimamente constituidos en Cortes generales y extraordinarias, y que reside en ellas la soberanía nacional» ${ }^{8}$. El sesgo revolucionario del primer decreto de las Cortes, promulgado el 24 de septiembre de 1810, da nacimiento al cuerpo representativo de la nación, determinando el rumbo ulterior de la elaboración de la Constitución de 1812, cuyo artículo tercero proclamaba que «la soberanía reside esencialmente en la nación y por lo mismo pertenece a ésta exclusivamente el derecho de establecer sus leyes fundamentales» ${ }^{9}$.

5. Ibid.

6. En el párrafo 97 del ensayo de Locke, que he consultado en su versión francesa: LOCKE, John. Traité du Gouvernement civil. París, Flammarion, 2008, p. 266.

7. SIEYĖs, Emmanuel Joseph. Qu'est-ce que le tiers état? préface de Jean-Denis Bredin, París, Flammarion, 1988, p. 40.

8. Diario de Sesiones de las Cortes generales y extraordinarias, $\mathrm{n}^{\circ} 1,24-\mathrm{IX}-1810, \mathrm{p} .3$.

9. Evocando los congresos y asambleas que se extendieron por la geografía hispana a partir de 1810, escribe José María PORTILlo VALDÉS: «[...] pensaron que podían restablecer el 
Partiendo de ese momento inaugural de la nación como sujeto de imputación de poder, esta aproximación se propone abordar la traducción iconográfica del cuerpo de la nación soberana, en tanto que representación del poder político. En la era liberal, la figura alegórica femenina, heredada de la iconografía tradicional de la monarquía, es la que viene a encarnar el cuerpo político de la nación soberana de los ciudadanos, hasta identificarse con el nuevo poder que se viene imponiendo, la democracia.

\section{El género de la nación}

Como lo recuerda el historiador Maurice Agulhon, el especialista de la imaginería y simbología republicanas, la representación visual de las ideas, como la justicia, la libertad, la ciencia o de «realidades más concretas pero demasiado amplias como para abarcarlas de una sola mirada (Francia, Alemania, París)» es una característica común a los países que pertenecen al área cultural europea de formación grecolatina ${ }^{10}$. En los siglos XVII y XVIII, cuando está perfectamente codificada la alegoría ${ }^{11}$, parece imponerse la representación de las monarquías europeas bajo la forma de figuras humanas acompañadas de atributos simbólicos, herederas de los dioses y diosas de la Antigüedad. Sin embargo antes de que se implantara la figura humana, la figura emblemática más antigua y común a casi todos los reinos europeos es el león cuya fuerza encarna simbólicamente la fuerza del jefe del reino ${ }^{12}$. El león pasa en la época moderna a caracterizar exclusivamente a la monarquía española, tomando los demás reinos europeos otros emblemas animales: el leopardo para Inglaterra, el águila para las Provincias Unidas, el gallo para Francia. En 1612, en la celebración de los esponsales de Luis XIII con la infanta Ana de Austria, la plaza Real de París estuvo enteramente adornada con gallos, atributos de Francia,

cuerpo de la monarquía convirtiéndolo en cuerpo de nación -como se quiso en Cádiz-o componiéndola ahora pueblos soberanos asociados en monarquía-como se intentó en Cundinamarca, Quito o Santiago de Chile», en «Cuerpo de nación, pueblo soberano. La representación política en la crisis de la monarquía hispana». Ayer, 61 (2006), p. 48.

10. AgulHon, Maurice. «La représentation de la France: quelques réflexions sur l'image féminine en politique». En M.-C. Hoock-Demarle (dir.). Femmes, Nations, Europe. París, Publications de l'Université Paris 7-Denis Diderot, 1995 p. 13.

11. MASSON, André. L'allégorie. París, PUF, Collection Que sais-je?, 1974, p. 5.

12. F. MENÉNDEZ PidAl señala el triple vínculo semántico que une el león y la monarquía: «leo fortis, rex fortis, leo rex» en su artículo «Symbolique d'État et armoiries des Royaumes espagnols». En XVIII. Internationaler Kongreß für Genealogie und Heraldik, 5-9 September 1988, Thaurdruck, Giesriegl Ges.m.b.H., Thaur/Tyrol, 1989, p. 418 (nota 2).

Feminismo/s 16, diciembre 2010, pp. 39-64 
y leones, atributos de España ${ }^{13}$. La pareja formada por el león y la alegoría femenina para representar a la monarquía española se impuso en la iconografía de exaltación de la realeza en el siglo XVII ${ }^{14}$. Posteriormente, reinando los Borbones, Tiépolo, en el Palacio Real edificado en la época de Carlos III, y Francisco Bayeu en 1794, bajo el reinado de Carlos IV, representan a la monarquía española bajo la doble figura de la efigie femenina y el león ${ }^{15}$.

La historiadora norteamericana Lynnn Hunt ha recalcado cómo en la Revolución Francesa las personificaciones femeninas sustituyeron la imagen del rey, asumiendo el desplazamiento del centro de poder ${ }^{16}$. En España, la ruptura política que significa para la monarquía la Guerra de la Independencia, ese «momento de la nación ${ }^{17}$, se traduce gráficamente en composiciones alegóricas que permaneciendo fieles a determinados códigos iconográficos del barroco confieren, sin embargo, mayor protagonismo a la imagen femenina que viene a plasmar la sublevación y resistencia a la invasión napoleónica en unión con Inglaterra. Así, toda una serie de estampas, en las que se escenifica a las dos monarquías bajo los rasgos de sendas matronas, celebran la alianza entre España e Inglaterra ${ }^{18}$. A pesar de su intención tradicionalista (defensa de la religión en la que se halla disparatadamente involucrada Inglaterra) y apologética (gloria de Fernando), la estampa «Triunfo de la Religión y del

13. Pastoureau, Michel. «Le coq gaulois». En P. Nora (dir.). Les lieux de mémoire, Les France. vol. III, París, Quarto Gallimard, 2004, p. 4305.

14. Como en el grabado de la toma de posesión de la corona por Carlos II en un almanaque de 1673 en el que la monarquía española está figurada por una matrona sentada en un trono con un león y un cetro (véase la colección Hennin, conservada en la Bibliothèque Nationale de France, $n^{\circ}$ 4664). De la misma forma, en la «Alegoría de la integración de Mesina a España» de Luca Giordano de 1678, España está figurada por una matrona romana con un león a sus pies en una profusa composición alegórica.

15. La «Glorificación de la monarquía española» de Tiépolo adorna el techo del salón del trono del Palacio Real de Madrid. El historiador Juan Francisco FUENTES evoca la composición pictórica de Bayeu en «La matrona y el león: imágenes de la nación liberal en la España del Siglo XIX». Archivos de la filmoteca: Revista de estudios históricos sobre la imagen, 66 (2010), pp. 44-67. Agradezco al autor el haberme dado a conocer este trabajo.

16. Hunt, Lynn. Politics, Culture, and Class in the French Revolution. Berkeley-Los Angeles, University of California Press, 1984.

17. «Para los patriotas insurgentes contra José I, no cabe ninguna duda de que el Estado ha sido destruido, y es la hora de la patria y la nación» escribe Javier Fernández Sebastián en «El momento de la nación. Monarquía, Estado y nación en el lenguaje político del tránsito entre los siglos XVIII y XIX». En A. Morales Moya (coord.). 1802. España entre dos siglos Monarquía, Estado, Nación. Madrid, Sociedad Estatal de Conmemoraciones Culturales, 2003, p. 74 (nota).

18. Véase el catálogo elaborado por Claudette DÉrozier en el tomo 2 de La Guerre d'Indépendance espagnole à travers l'estampe (1808-1814). Lille, Atelier Reproduction des thèses, Université Lille III, Paris, Librairie Honoré Champion, 1976. 
Rey Fernando con exterminio del Tirano a impulsos de las dos heroicas Naciones unidas» ${ }^{19}$ (Fig. 1) viene a subrayar el protagonismo de la nación española, representada por una parte en la matrona acompañada por el león y por otra parte por la figura duplicada del león en lucha encarnizada con José Bonaparte, es decir contra el poder usurpador. En esta estampa, como en otras, el retrato celeste, en medallón, de Fernando señala la presencia simbólica del monarca español a la vez que su ausencia física y por consiguiente la actuación terrestre y -podríamos decir- «soberana» de la nación española plasmada en la efigie femenina.

La promulgación de la Constitución de 1812 daría lugar a

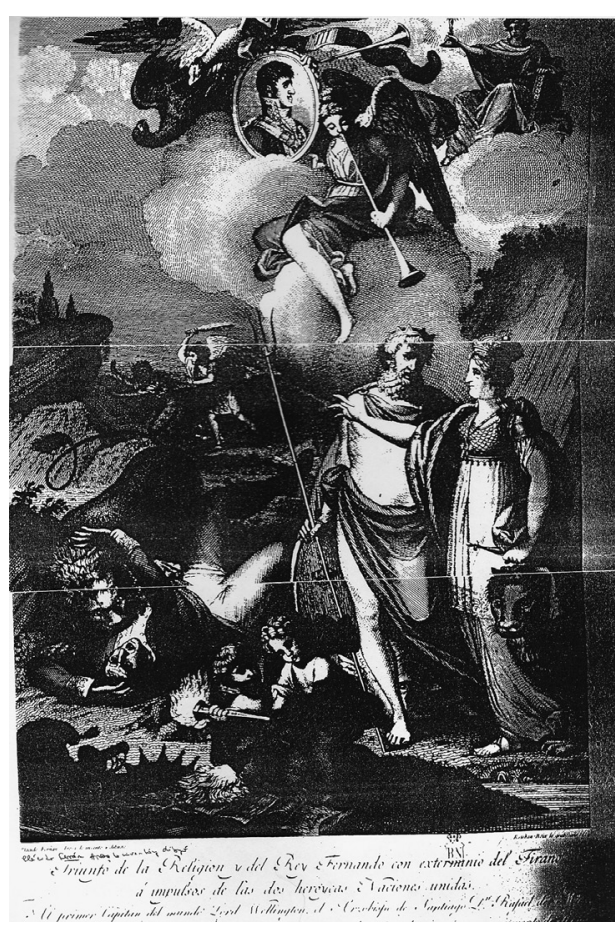

Figura 1. escenografías urbanas, como la organizada en Teruel por las autoridades municipales. Una diosa de la libertad, identificada como «libertad constitucional», rodeada de los símbolos del saber (libro), de la abundancia (espigas de trigo) y de la ciencia pisa triunfante «un monstruo vestido de negro con un puñal en la mano que significaba el despotismo y tiranía $»^{20}$. Esta composición alegórica anticipa los elementos

19. Este grabado se conserva en la BNE, invent/ 14961. Al pie de la imagen se leen las indicaciones siguientes: «Plácido Ferrán Arosa lo inventó y dibujó», «Esteban Boix lo grabó año 1814». Este grabado encargado por el arzobispo de Santiago, Don Rafael de Murquiz, está dedicado a Lord Wellington: «Al primer Capitán del mundo Lord Wellington, el Arzobispo de Santiago Don Rafael de Murquiz, quien en el año 1808 dispuso que a sus expensas se grabase esta lámina como monumento de eterna gratitud y alianza con la Gran Bretaña». Claudette DÉROZIER comenta que dicho proyecto iconográfico podía albergar en 1808, por parte del arzobispo, el propósito de aplacar las reticencias para con la alianza contra Inglaterra (Op. cit., p. 745).

20. Esta celebración urbana se relata en un documento conservado en el Archivo Histórico Nacional y la comenta LARRAZ, Emmanuel. Théâtre et politique pendant la guerre d'indépendance espagnole: 1808-1814. Aix en Provence, Université de Provence, 1988, pp. 282-284.

Feminismo/s 16, diciembre 2010, pp. 39-64 


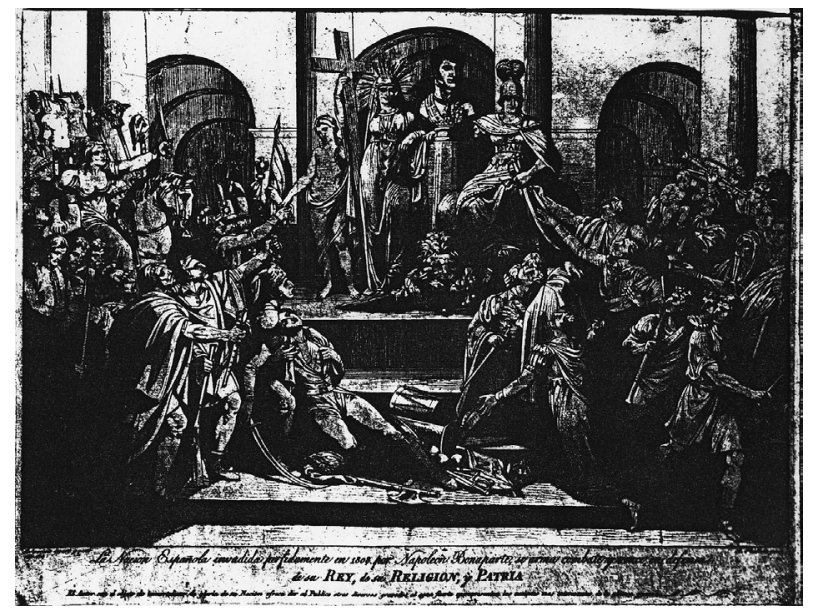

Figura 2.

constitutivos de la imaginería liberal (el combate de la libertad contra el despotismo) y luego la republicana que vincularía la noción de libertad política con la ciencia, las artes y la abundancia, en torno a una idea que escasamente se expresa a principios del XIX, la de progreso.

Si bien parece aclimatarse en la imaginería de la Guerra de la Independencia la alegoría femenina, recuperada de la iconografía del poder monárquico, para figurar a la nación, una curiosa y recargada estampa de 1814, dibujada por Aparicio y grabada por Pinelli, titulada «La Nación Española invadida pérfidamente en 1808 por Napoleón Bonaparte, se arma combate y vence en defensa de su REY, de su RELIGIÓN, y PATRIA» (Fig. 2), de inspiración davidiana, presenta la novedad y singularidad para la época de encarnar a la nación española bajo la forma de una abigarrada muchedumbre ${ }^{21}$. En esta estampa se yerguen en el estrado, en torno al busto de Fernando VII, las alegorías

21. BNE, invent/14934 e invent/23073 (existe una versión digitalizada en la Biblioteca Digital Hispánica de la BNE). Éste es un grabado preparativo de un lienzo de monumentales dimensiones que acabó Aparicio en 1818, véase el artículo de HERNÁNDEZ GuARDIOLA, Lorenzo. «Un discípulo de la Academia de San Carlos: José Aparicio Inglada (1770-1838), pintor neoclásico español». Archivo de Arte Valenciano, 88 (2007), p. 328. Otra versión de esta estampa (Pomares, dibujante, Pinelli, grabador), bajo forma de esbozo, se reproduce en el catálogo Colección de grabados. Guerra de la Independencia 1808-1813. Álava, Museo de Armería de Álava, Diputación foral de Álava, 1997, plancha $\mathrm{n}^{\circ} 2$. En este grabado no están ni el busto del rey ni la figura de «Marianne». En cambio, el elemento femenino está representado por una joven y una madre con su hijo en brazos. Indica el catálogo que estos grabados fueron «hechos por el italiano Pinelli, en 1820 de su visión de la Guerra de 'la independencia' de España» (p.»). 
femeninas de la religión, de España (como Minerva con casco) acompañada del león, mientras entre la multitud que emula a la representada en el lienzo de David, «Le serment du Jeu de paume», una joven de pecho descubierto, montada a caballo, sujeta una antorcha o tea, como trasunto de la Marianne francesa. Por tanto, la figura femenina -con apariencia bien diferenciada, la desordenada y escasa indumentaria de la carnosa y popular «Marianne» dista mucho del porte hierático y romano de la Religión y de «Minerva-España»sintetiza las ideologías opuestas y reunidas en la España sublevada contra Napoleón: tradición y liberalismo.

La multiplicación de las efigies femeninas para encarnar a la nación española, como poder en gestación, se simultanea con el surgimiento de figuras alegóricas masculinas: el león y el genio del patriotismo. En efecto, la abundante producción gráfica de la época de la Guerra de la Independencia consagra al león, no ya como emblema de la monarquía, sino como encarnación de la nación española. Así lo indica explícitamente una inscripción que figura en una pintura anónima de principios del siglo XIX, Imagen de Jura con retrato de Fernando VII, «Este león que es la Nación Española jamás soltará de sus garras los dos Mundos de Fernando VII ${ }^{22}$. Ese traslado semántico podría explicarse por dos razones: una histórica, el esfuerzo del pueblo español en la resistencia contra la invasión, y otra gráfica, el león con la fuerza de sus fauces y garras es el que plásticamente se opone y vence al águila o gallo francés, emblema de Francia, lucha alegórica tópica de las estampas de la época ${ }^{23}$. Por la figura del león la Francia revolucionaria había simbolizado la fuerza popular, como lo recuerda Agulhon ${ }^{24}$, quien especifica que «la Liberté du XIXè siècle [est] presque toujours associée à l'animal lion (symbole emprunté à la panoplie du pouvoir) $»^{25}$. La figura masculina del genio del patriotismo encarna la fuerza y el arrojo. Suele aparecer bajo la forma de un Marte alado como en la estampa titulada «Alegoría de la Guerra de la Independencia» ${ }^{26}$ en la que también se alegoriza la guerra bajo la forma de la lucha encarnizada entre el águila,

22. Víctor MínGUEZ evoca este lienzo que se conserva en el Museo Regional de Guadalajara, México, en su artículo «La iconografía del poder. Fernando VII y José I. Apoteosis y escarnio en la disputa del trono español». En A. Ramos Santana y A. Romero Ferrer (eds.). 1808-1812: los emblemas de la libertad. Cádiz, Servicio de publicaciones de la Universidad de Cádiz, 2009, p. 176.

23. El catálogo Estampas de la Guerra de la Independencia. Madrid, Ayuntamiento de Madrid, 1996, contiene numerosos ejemplos de esa lucha animal que a veces duplica otra escena de combate.

24. Véase Agulhon, Maurice y Bonte, Pierre. Marianne. Les visages de la République. París, Gallimard, 1992, pp. 15 y 39.

25. Agulhon, Maurice. Marianne au combat. París, Flammarion, 1979, p. 25.

26. En Estampas de la Guerra de la Independencia... Op. cit., p. 149.

Feminismo/s 16, diciembre 2010, pp. 39-64 


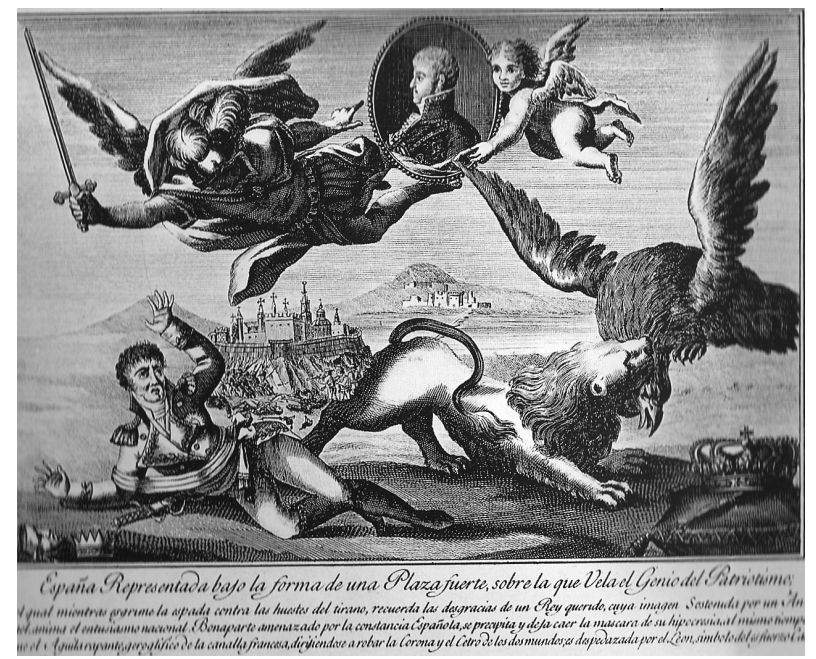

Figura 3.

«geroglífico ( $\mathrm{sic}$ ) de la canalla francesa» y el León (con mayúscula), «símbolo del esfuerzo cast. ${ }^{n o} \gg$ (Fig. 3). Es decir, si el león y el genio armado del patriotismo vienen a encarnar la fuerza concreta, la alegoría femenina, recuperada de la retórica gráfica del barroco, representa este poder simbólico que está emergiendo: la nación. En cierta forma, en estas escenografías alegóricas mixtas -que mezclan lo animal y lo humano, lo femenino y lo masculino- el reparto de género emula la que era representación tradicional de la monarquía -el rey, como poder concreto, histórico- y la alegoría femenina como encarnación de la institución monárquica, como poder simbólico de la realeza.

Tanto la alegoría de España tomada prestada de la iconografía barroca, como el león o el genio del patriotismo, y mucho más escasamente la muchedumbre abigarrada, configuran, en el contexto de la Guerra de la Independencia, a la nación española en tanto que actor político colectivo. La mayoría de estas escenografías incluyen un retrato de Fernando VII, protagonista pasivo, valga el oxímoron, de las composiciones alegóricas. Este retrato, abundantemente reproducido en las escenas alegóricas, forma parte de un dispositivo propagandístico que apunta a mitificar al soberano víctima de Napoleón, como lo han subrayado el hispanista Claude Morange y más recientemente Emilio La Parra ${ }^{27}$. Pero el retrato de Fernando, puesto en escena, y, en cierta

27. Respectivamente en «La «Révolution espagnole» de 1808 à 1814. Histoire et écritures». En C. Morange, J.-R. Aymes, G. Brey, A. Lacour, A. Dérozier. La Révolution 
forma, instrumentalizado, también se muestra como símbolo de la cohesión nacional y como herramienta de propaganda que ha de suscitar el impulso colectivo contra la invasión y la dinastía intrusa. Por lo que, en el contexto bélico, el retrato de Fernando es menos apología de la monarquía que propaganda de la misma nación. El retrato en medallón o el busto de Fernando forma parte del arsenal simbólico de las señas de identidad de la nación. Antonio Alcalá Galiano, al evocar en sus memorias los primeros momentos de las Cortes de Cádiz, señala la presencia en el salón de las sesiones de las Cortes de un «un retrato del rey bajo dosel, custodiado por guardias de la real persona, lo cual por fuerza significaba estar la majestad real allí presente ${ }^{28}$, subrayando la importancia de los emblemas que «algo significan, porque de algún pensamiento nacen y alguna idea están destinados a expresar ${ }^{29}$. En cierta forma, Fernando representado en medallón de cabeza del cuerpo de la monarquía pasa a convertirse en emblema del cuerpo de la nación.

\section{La España liberal: de la reina-nación a la mater dolorosa}

Si bien la Guerra de la Independencia había hecho emerger una alegoría femenina emancipada de la monarquía e identificada con la nación en ciernes, no cabía duda de que las mujeres, como tales, quedaban excluidas de esa misma construcción nacional. Es decir, como en los demás procesos de construcción nacional en Norteamérica y en Europa, en la primera andadura liberal española que se desarrolla en la coyuntura bélica, el cuerpo femenino se hace simbólicamente el portador de la nación, pero se le niega a las mujeres cualquier relación activa con esa misma construcción nacional ${ }^{30}$ y con el nuevo poder, derivado de la soberanía nacional, que se está forjando.

La conflictiva relación entre poder y mujer se haría especialmente evidente con el acceso al trono de la hija de Fernando VII, Isabel II, en 1833. La

française et son «public» en Espagne entre 1808 et 1814. Annales Littéraires de l'Université de Besançon. París, Les Belles Lettres, 338 (1989), p. 33 y en «El mito del rey deseado». En Sombras de mayo. Mitos y memorias de la Guerra de la Independencia en España (1808-1908), Madrid, Casa de Velázquez, 2007, pp. 221-236.

28. Alcalá Galiano, Antonio. Memorias de D. Antonio Alcalá Galiano, Edición digital a partir de Obras escogidas. Recuerdos y memorias. T. I, Madrid, Atlas, 1955, capítulo XVII.

29. Ibid.

30. Véase MCCLINTOCK, Anne. «No Longer in a Future Heaven», citada por WENK, Silke en «Gendered Representations of the Nation's Past and Future». En I. Blom, K. Hagemann y C. Hall (eds.). Gendered Nations. Nationalism and Gender Order in the Long Nineteenth Century, Oxford-New York, Oxford International Publishers, 2000, p. 67. Señalemos que el reparto de género que caracteriza la construcción nacional no sólo afecta a Estados Unidos y Europa sino otros países, ya que Anne McClintock evoca el ejemplo surafricano en su artículo.

Feminismo/s 16, diciembre 2010, pp. 39-64 


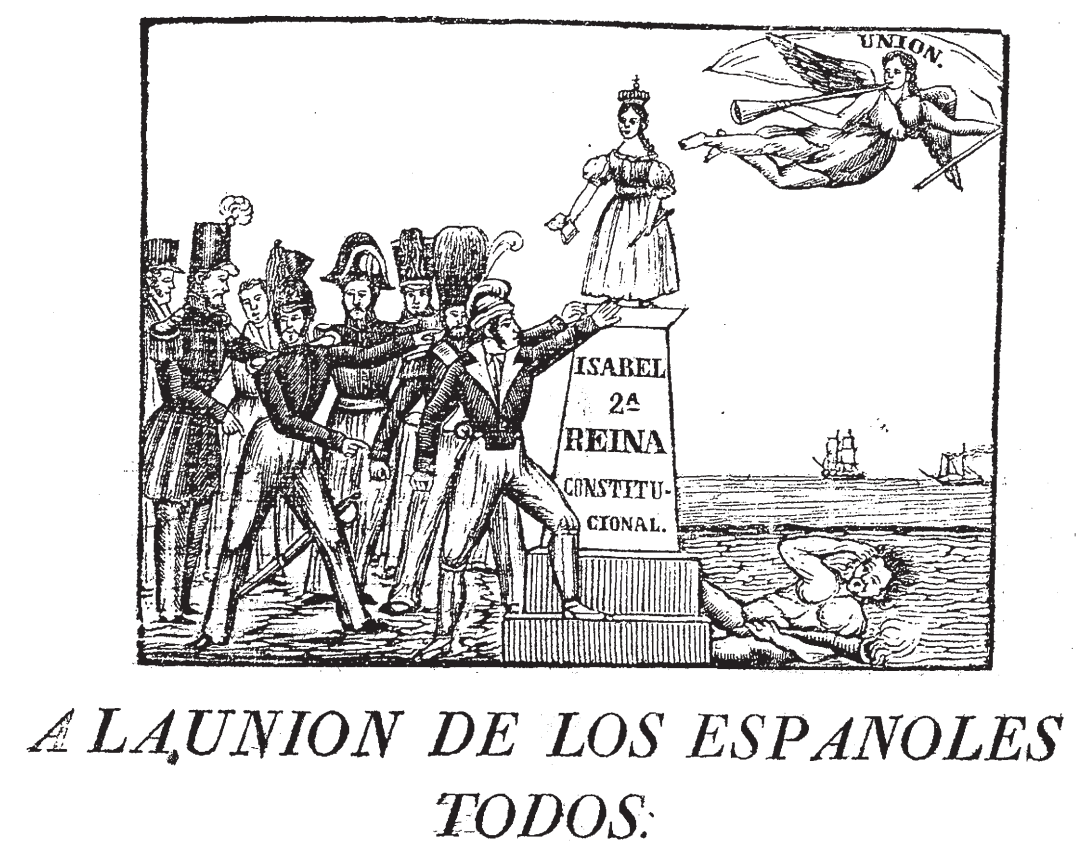

CORO.

Frez-y glaria al paliente soldado

que en lás. ildes mil veces venció:

Prety glorid al valiente paisano,

que eon za traidor derrocó.

Figura 4.

feminidad de Isabel II fue un problema político desde el principio, como lo subraya Isabel Burdiel, y no sólo por la consecuencia política e histórica más espectacular que arrastró, la primera guerra carlista ${ }^{31}$. En efecto, coincidió el reinado de Isabel II con la asunción de un nuevo orden social y político que marginaba a las mujeres del espacio público, recluyéndolas en la esfera privada y consagrando un modelo femenino identificado con la moralidad y abnegación, el ángel del hogar. Un modelo con el que desde luego no encajaría la personalidad y la desordenada vida privada de la soberana que, por otra parte, fue el constante instrumento de los intereses políticos primero de su madre y luego de los moderados.

Desde el inicio, hubo una auténtica instrumentalización de la figura de la joven Isabel II, heredera del trono, con sólo tres años, a la que se convierte en

31. BURDIEL, Isabel. Isabel II. No se puede reinar inocentemente. Madrid, Espasa Calpe, 2004, pp. 25-26. 
emblema de la libertad y progreso en oposición al absolutismo y al oscurantismo carlistas ${ }^{32}$. El contexto bélico, la niñez e inocencia de Isabel, la movilización popular en pro de la defensa de las libertades parecen emular el impulso de resistencia de la Guerra de la Independencia. De ahí que la iconografía de la literatura de cordel de la época convoque un arsenal simbólico que en parte se había venido forjando en la imaginería de la Guerra de la Independencia -el león identificado con la nación española, el genio del patriotismo, el monstruo del despotismo derrotado, la lápida constitucional- al que se suman la niñez y feminidad de Isabel, convertidas en motivos icónicos.

Al respecto, dos imágenes me parecen paradigmáticas de la instrumentalización de la figura femenina de la joven reina Isabel II por la propaganda liberal: un lienzo de José Ribelles y Elip «Alegoría de España con María Cristina e Isabel II $»^{33}$ (Fig. 4) y el encabezamiento gráfico de un romance impreso en Barcelona probablemente en 1843 «A la unión de los españoles todos» ${ }^{34}$ (Fig. 5). Dos imágenes situadas, por otra parte, en momentos claves del reinado de Isabel, la primera en la aprobación del Estatuto Real, es decir en el tránsito entre absolutismo y liberalismo, la segunda en la mayoría de edad de la joven soberana. A pesar del estilo diferente -una pintura académica de corte clasicista y un sobrio grabado en madera- ambas representaciones exaltan la monarquía liberal, en su combate contra el carlismo en el primer caso, y unida al pueblo (confraternizan en el grabado paisanos y soldados) en el segundo, incluyendo a la joven monarca en una composición narrativa.

El lienzo de Ribelles, aunque fuertemente influido por los códigos iconográficos barrocos (los putti que llevan el manto de armiño de Isabel, otro putto con horca, atributo de la agricultura, la imagen celeste de Minerva, diosa

32. GUTIÉRREZ LLORET, Rosa Ana. «Da icona della libertà a disonore della Spagna: immagini della regina Isabella II nel processo di legittimazione sociale e politica della prima monarchia liberale spagnola (1830-1868)». En G. Guazzaloca (ed.). Sovrani a metà. Monarchia e legittimazione politica tra Otto e Novecento, Soveria Mannelli, Ed. Rubbetino, 2009, p. 137.

33. Agradezco sinceramente a Rosa Ana Gutiérrez Lloret que me haya dado a conocer este cuadro que se conserva en el Museo del Romanticismo de Madrid. La datación indicada por el Museo es en torno a 1833. Lo más probable es que sea de 1834, por ser el cuadro claramente una exaltación de Martínez de la Rosa, autor del Estatuto Real. Se dan diversas ortografías del nombre del pintor: «Ribelles y Felip», «Ribelles y Helip». Explica José Luis BARRIO MOYA que el segundo apellido es «Felip», la ortografía «Helip» resulta de un error de lectura. Ribelles se hizo masón durante la ocupación francesa y tuvo que vérselas con la inquisición cuando regresó Fernando VII a España. Posteriormente, en 1819, Ribelles obtuvo el cargo de pintor honorario de Cámara. Véase su artículo «Aportaciones a la biografía del pintor valenciano José Ribelles y Elip (1775-1835)». Archivo de arte valenciano, 76 (1995), pp. 162-171.

34. «A la unión de los españoles todos», Barcelona, Imprenta de Francisco Vallés, s.f.

Feminismo/s 16, diciembre 2010, pp. 39-64 


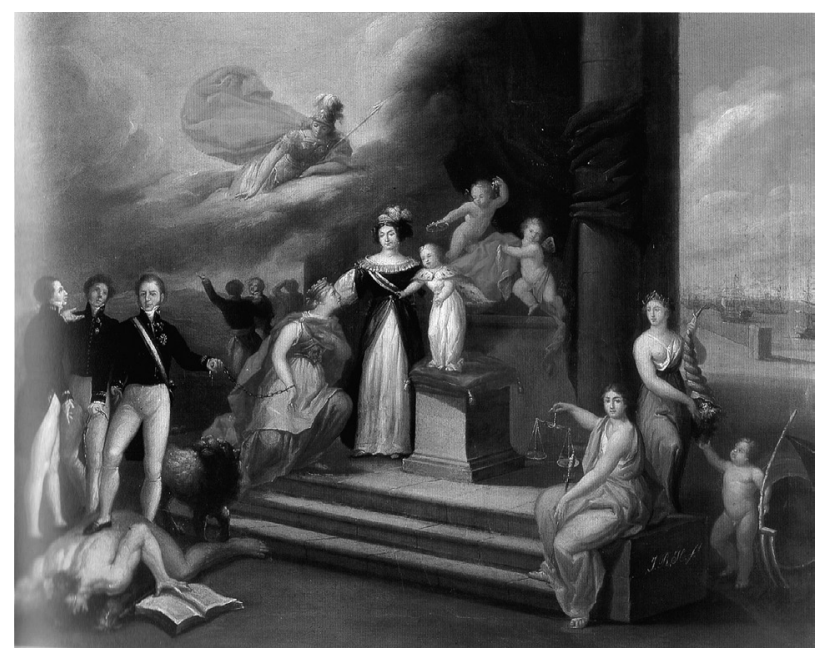

Figura 5.

de la sabiduría, pero aquí representada como diosa guerrera, las alegorías de la abundancia y de la justicia), exalta el combate liberal victorioso contra la tiranía que viene representada bajo la forma de una figura masculina, forzu$\mathrm{da}$, que acaban de tumbar a tres hombres, entre quienes se puede reconocer a Martínez de la Rosa ${ }^{35}$. Éste pone el pie en el monstruo del despotismo vencido, el cual está armado de la tea incendiaria de la discordia y tiene los ojos vendados como la ignorancia. La tiranía derrotada se encarna doblemente en, por una parte, el monstruo derribado y, por otra, la cadena rota que aherrojaba a España representada como matrona de porte romano, tocada con la corona almenada. Ésta rinde pleitesía a la reina Isabel II acompañada de su madre María Cristina. La reina gobernadora sirve de vínculo de unión entre la alegoría de España y la reina niña, poniéndose de relieve, formal y simbólicamente, el papel político de María Cristina. La joven Isabel II tiene claros visos de niño Jesús, en efecto no se sugiere nada la feminidad de la niña, subrayándose así hiperbólicamente el papel mesiánico de la reina niña. En la composición, de evidente corte clasicista, domina el triángulo: en la base a la izquierda los liberales y a la derecha aquellas virtudes relacionadas con la monarquía tradicional: la justicia (con la balanza de platillos equilibrados y la espada no levantada sino hacia abajo en signo de paz), la prosperidad, formando la reina

35. Quizás los otros dos personajes de este trío sean el conde de Toreno y Javier de Burgos. Agradezco a Claude Morange su generosa ayuda en esta identificación. 
niña la cúspide de la composición triangular. Contrastan fuertemente los dos laterales del cuadro: a la izquierda el contexto agitado de la guerra (carlista) con su eco (romántico) en el cielo tormentoso, dominado sin embargo por la figura de Minerva (como anuncio de victoria); a la derecha un paisaje sereno, de cielo azul, con un puerto asociado con la actividad comercial, los viajes y la prosperidad. De hecho, se puede relacionar este fuerte contraste entre la parte izquierda y la parte derecha con el aspecto narrativo, tan del gusto de la pintura clásica, desde la bestia del despotismo vencida hasta la reina niña/Mesías que augura un futuro (a la derecha) de prosperidad, paz y justicia. Según Carlos Reyero, el cuadro de Ribelles representa más una monarquía de Antiguo Régimen que constitucional ${ }^{36}$. No comparto plenamente esta opinión; creo más bien que aparece el combate liberal como primordial o fundamental para la asunción monárquica: el grupo de los liberales que vence a la tiranía aparece a la izquierda, es decir según el eje de lectura de izquierda a derecha, por lo menos para un espectador occidental, como anterior y como tal esencial a la accesión al trono de Isabel II. En todo caso tendríamos aquí un ejemplo de transición o enlace entre la representación barroca de la monarquía y su versión en clave liberal.

Con esta pintura oficial coincide toda una imaginería política de exaltación de la joven Isabel II como reina constitucional, que recoge parte del arsenal simbólico del que echaba mano Ribelles. Éste es el caso de una alegoría de la Constitución de 1837 en la que la joven soberana, cuya feminidad viene recalcada (a pesar de sus escasos siete años), sujeta el libro de la Constitución, que descansa en una columna junto con los emblemas de la monarquía (corona cerrada y Toisón de oro), completando el león que yace a los pies de la columna esta escenografía de la monarquía constitucional ${ }^{37}$. En la imagen que sirve de encabezamiento al romance barcelonés citado más arriba se plasma la nación española en una representación metonímica del pueblo en la que confraternizan el ejército y los paisanos, codeándose entre éstos el payés (tocado de la barretina) y el burgués (con sombrero de copa) que aclama a la reina niña colocada en un pedestal y con aire de virgen, pero con atributos «laicos» y claramente políticos, el cetro y el libro de la Constitución, síntesis gráfica de la monarquía constitucional. Tras la confabulación moderado-progresista que había acabado con la regencia de Espartero -el romance denuncia la traición de los «ayacuchos»- la joven reina concentra todas las esperanzas de

36. REYERO, Carlos. «Pintar a Isabel II: en busca de una imagen para la reina». En J.S. Pérez Garzón (ed.). Los espejos de la reina. Madrid, Marcial Pons Historia, 2004, p. 235.

37. Se conserva un ejemplar de este grabado en la BNE, invent/15011.

Feminismo/s 16, diciembre 2010, pp. 39-64 
renovación y conciliación de los partidos ${ }^{38}$, esto es lo que escenifica el grabado. La viñeta ofrece, a través de la fervorosa unión entre la corona y el pueblo, una imagen de la nación aún compartida por progresistas y moderados. Los festejos organizados con ocasión de la mayoría de edad de Isabel II pusieron de relieve la juventud y la inocencia de la joven reina. En Sevilla, por ejemplo, uno de los elementos de la arquitectura efímera había de comportar "palomas, y guirnaldas de flores, como símbolo de la inocencia y de la gracia ${ }^{39}$. La difusión de la imagen de la reina niña pura e inocente como emblema del liberalismo se compagina con el uso de una retórica religiosa en la que se asocia a la reina niña con el niño Jesús o con la imagen mariana.

En la imaginería política de mediados del siglo XIX, si bien la reina Isabel II se integra en escenografías que plasman la monarquía constitucional, en tanto que alianza entre la corona y el pueblo, la figura del león se afianza como emblema de la nación española y específicamente del pueblo español. Un romance popular, probablemente de 1840, para evocar el sublevamiento de la «heroica villa de Madrid» contra la ley municipal, identifica al león con el pueblo: «Al fin, el león de España/ con noble arrojo se alzó./ Y su imponente rugido/ por todo el reino sonó./ Este león es el pueblo/ que valiente y liberal/ siete años que defiende/ la ley constitucional $\gg^{40}$. Un grabado alegórico de la Sociedad de Tejedores de Barcelona que celebra la industria, la agricultura y el comercio confirma al león como emblema nacional. Explica el pie de la imagen: «Lo llaó emblema de la forsa y de la nació Española (sic) aguantan lo lletrero o dona a entendre que la Espanya sempre defensará la industria, la agricultura y el comers ${ }^{41}$.

La posterior guerra de Marruecos de 1859-1860, que se incluye en las expediciones militares de la época de dominio de la Unión Liberal de O'Donnell, consagra a la figura del león, convirtiéndolo en elemento clave de la retórica nacionalista y patriotera que se consolidó entonces. La literatura de cordel de la época se llena entonces de leones rugientes que repentinamente salen de su

38. BuRdiel, Isabel. Op. cit., pp. 219-220.

39. Como lo indica el Programa de las funciones públicas acordado por el Ayuntamiento de Sevilla los días 19, 20 y 21 de noviembre de 1843. Sevilla, Imprenta del Sevillano, 16 de noviembre de 1843, documento impreso conservado en la Hemeroteca Municipal de Madrid, A.1231.

40. Pronunciamiento de la heroica villa de Madrid, unida con el ejército. Barcelona, Librería de José Lluch, s. f.

41. Festivitat que selebra (sic) la societat de teixidos (sic) de Barcelona. Barcelona, Imprenta de C. Miró, s. f. Juan Francisco FUENTES evoca este grabado en su artículo «Iconografía de la idea de España en la segunda mitad del siglo XIX». Cercles d'Història cultural, Universitat de Barcelona, 5 (2002), pp. 8-25. 
letargo: en tal romance aparece el león del que se creía que ya nunca más despertaría ${ }^{42}$, en otro el rugido del león suena en toda Europa ${ }^{43}$, en otra parte el rugido del león rima con el trueno del cañón ${ }^{44}$. Está claro que en la coyuntura bélica, el león es la alegoría de España, en una demostración de fuerza ante las potencias europeas. El «león hispano» vencedor de la «pantera africana» anticipa la retórica nacionalista de la guerra hispanoamericana de 1898 que presentará al león dormido español descuartizando al cerdo yanqui.

Mientras el león se hace emblema de la consolidación del Estado liberal en su vertiente nacionalista y se explaya la alegoría de España bajo los rasgos de una noble y reposada matrona, en las fachadas y paredes de los monumentos oficiales ${ }^{45}$, los primeros pasos de la caricatura de prensa en la década de los treinta y cuarenta significan el divorcio gráfico entre la otrora reina-niña-nación, imagen propagandística consolidada en la primera guerra carlista, y una España a la que se representa con los rasgos de una matrona menos airosa, humanizada o incluso martirizada. El cuerpo femenino es el que mejor va a prestarse a encarnar los dolores de una nación presa de los políticos corruptos, la mater dolorosa, que da título a la obra de José Álvarez Junco sobre la idea de España en el siglo XIX ${ }^{46}$. El progresista Sancho Gobernador ${ }^{47}$ publica el 1 de enero de 1837 una «España crucificada, torturada y

42. «Se creían que el León/ nunca más despertaría», en el romance Declaración de guerra que hace la España indignada, al imperio de Marruecos. Barcelona, José Torras, Imp. de Francisco Sánchez, 1859. La lámina que encabeza el romance evoca la firma de la declaración de guerra por Isabel II, a quien aclaman los miembros del gobierno y los militares.

43. La fama española. El sable de Prim. Barcelona, José Puig y Malagarriaga, Imp. Económica a cargo de José Antonio Oliveres, 1860.

44. Suplemento a El cañón rayado. ¡Viva España! ¡Viva el ejército de Africa!. Barcelona, Imp. de Luis Tasso, 1860. La composición poética es de Víctor Balaguer. Así reza el principio del estribillo: «iVictoria! La anuncia/ rugiendo el león./ Victoria proclama/ tronando el cañón». En sus memorias, Conrad ROURE indica que esta publicación, El cañón rayado, dirigida por Antonio Altadill, estaba enteramente dedicada a la guerra de Marruecos, en Recuerdos de mi larga vida. Barcelona, El Diluvio, 1925, T. 1, p. 148.

45. Por ejemplo: el frontón del palacio del Congreso de los diputados, cuyo asunto había de incluir a «la España abrazando la constitución del Estado», tal como reza el programa aprobado por Isabel II en 1848 (Archivo de la Academia de Bellas Artes de San Fernando, carpeta 28-4/2), los frescos del interior del mismo palacio o la fachada de la Biblioteca Nacional, entre otros.

46. ÁlVAREZ JunCO, José. Mater dolorosa. La idea de España en el siglo XIX. Madrid, Taurus, 2001.

47. Ana María García Rovira identifica esta publicación con el republicanismo junto con El Corsario. Véase su artículo «Radicalismo liberal, republicanismo y revolución (1835-1837)». Ayer, 29 (1998), pp. 63-90.

Feminismo/s 16, diciembre 2010, pp. 39-64 
saqueada $»^{48}$, en la década siguiente, en la moderada La Postdata, España toma la apariencia de una joven Blandina descuartizada no por leones sino por una manada de lobos que representan a los «ayacuchos», o aparece desangrada por ministros-sanguijuelas ${ }^{49}$. Un par de décadas más tarde, Francisco Ortego, caricaturista colaborador habitual del semanario Gil Blas, de simpatías demócratas, denuncia el endémico pretorianismo, representando a España con el aspecto de una desvalida y asustada matrona acompañada de un león que en vano intenta espantar a cuatro militares que, con las espadas desenvainadas, la están acorralando ${ }^{50}$. La pareja mixta -por mezclar lo femenino y lo masculino, así como lo humano y lo animal- formada por la matrona y el león como alegoría de España, afianzada a lo largo de la era liberal, se popularizaría en el Sexenio Democrático para expresar de forma jocosa y sarcástica las esperanzas revolucionarias finalmente defraudadas.

\section{Entre Hispania y Mariana}

Si bien la revolución de 1868 culmina el concepto de política en tanto que espacio público de igualdad entre ciudadanos al inscribir en la Constitución de 1869 el sufragio universal, consagra, paradójicamente, la desigualdad de la mujer al marginarla de la ciudadanía por razones sociales y culturales: no entra ni en la misión ni en la función de la mujer participar en la vida política. Sin embargo, en el terreno de las representaciones políticas, la figura femenina en la que había encarnado alegóricamente el liberalismo español a la nación soberana llega a cobrar en el Sexenio Democrático un protagonismo creciente hasta identificarse con el poder del pueblo.

Simbólicamente, al día siguiente del destronamiento de Isabel II, se figura a la nación dueña de sus destinos y no ya de una dinastía, sustituyendo en la cabecera de La Gaceta de Madrid el escudo de armas de los Borbones por una alegoría femenina con balanza de la justicia y caduceo, acompañada de un león y un gallo, y que pisa un perro, símbolo de la tiranía o la discordia ${ }^{51}$. La soberanía nacional, encarnada en el cuerpo femenino, diseñada seguramente

48. La imagen figura precisamente en la portada del ensayo de ÁlvAREZ JunCO, José. Op.cit.

49. Respectivamente, La Posdata, 1842 (sin mes) y La Posdata, octubre de 1843. Grabado conservado en la BNE, invent/17959. Juan Francisco FUENTES comenta esta segunda imagen en «Iconografía de la idea de España...» Op.cit., p. 14. La Postdata (1842-1843) con El Cangrejo (1841) forman parte de la prensa de signo moderado nacida en oposición a la política de Espartero.

50. Gil Blas, 14-I-1865, p. 3. Juan Francisco FUENTES comenta esta imagen en «Iconografía de la idea de España...» Op.cit., p. 14. Los cuatro militares son probablemente: Narváez (presidente del gobierno a la sazón), Prim, Espartero y O’Donnell.

51. La Gaceta de Madrid, 30-IX-1868. 
en la emergencia, cobra visos claramente republicanos al incluirse en la composición al gallo, directamente heredado de la iconografía francesa. En efecto, el gallo había experimentado una evolución semántico-política parecida a la del león en la iconografía española: tras asimilarse con la monarquía francesa (como lo hemos visto más arriba), cobró en el período revolucionario francés un simbolismo identificado con la libertad y el pueblo victorioso, hasta llegar a ser uno de los emblemas de la República francesa ${ }^{52}$. En la imaginería política española, ya a principios de la era isabelina, el gallo se asimilaba con la libertad por una especie de procedimiento silogístico: el gallo es el emblema de Francia, Francia es el país de la libertad, el gallo es pues el símbolo de la libertad $^{53}$. En el Sexenio Democrático, la propaganda republicana española aclimatará este mismo símbolo foráneo.

$\mathrm{Al}$ año siguiente, ostenta el encabezamiento de La Gaceta de Madrid una figura femenina mucho menos revolucionaria, recostada en el escudo de España y acompañada del león ${ }^{54}$. La imagen emblema de la España democrática sigue, de hecho, el dictamen emitido por una comisión mixta que, a petición del Gobierno provisional, había reunido a miembros de las academias de Historia y de Bellas Artes para elaborar la efigie de España que había de figurar en los nuevos cuños ${ }^{55}$. La comisión se inspira en el ejemplo de países como Inglaterra, Suiza o Francia, que ostentan en sus monedas alegorías femeninas para representar a la nación soberana. Siguiendo especialmente el ejemplo de la Francia del 48 que «para simbolizar la República, tomó una bellísima cabeza de las medallas sicilianas antiguas $»^{56}$, propone la comisión la figura de España, Hispania, grabada en el reverso de algunas medallas del emperador Adriano. Se concreta pues la proposición de la Comisión en una «matrona recostada en los Pirineos, rodeada del Océano, con los pies en el Estrecho, la rama de oliva en la mano y la diadema en la cabeza, que será el símbolo pedido de la soberanía de la nación ${ }^{57}$. La reposada matrona geográfica es la encargada de encarnar la ruptura revolucionaria y la asunción democrática, pero se trata de una figura enraizada en la historia, la alegoría romana, con un toque

52. Así lo explica Michel Pastoureau en su obra Les emblèmes de la France. París, Éditions Bonneton, 1998, véase la entrada «Coq», pp. 62-83.

53. Por ejemplo en el romance en catalán de la época de la revolución de 1840 Cansó Patriótica. Lo gallet del liberal, per un poeta llemosí. Barcelona, Imprenta de Bosch y Compa , s. f.

54. A partir de 1 de enero de 1869.

55. El informe remitido por la comisión, con fecha de 6 de noviembre de 1868, está publicado en el Boletín de la Real Academia de la Historia, IV, 1884, pp. 186-191.

56. Ibíd., p. 186.

57. Ibíd., p. 187.

Feminismo/s 16, diciembre 2010, pp. 39-64 
propiamente hispánico, ya que el emperador Adriano había nacido en la Bética. Como ya lo hiciera notar el medievalista Pastoureau, los símbolos no nacen de la nada, son constantes préstamos resemantizados. Era lo que había pasado con la simbología de la Francia revolucionaria deudora de la simbología romana. En el caso de la España del Sexenio, la figura femenina encargada de representar el poder oficial de la nación, rescatada de la antigüedad por los académicos, saca su legitimación a la vez de la ruptura revolucionaria y de la tradición histórica. Esta imagen femenina del poder de la nación es la que se acuña en la recién creada peseta en 1869 , llevando la moneda de 5 pesetas de 1869 inscrita en el canto el lema «soberanía nacional $»^{58}$; de la misma forma esta efigie alegórica de España se pone en circulación en los sellos de correos a partir del 1 de junio de $1870^{59}$.

Simultáneamente, la libertad de expresión conseguida desde los primeros decretos emitidos por el gobierno provisional en octubre de 1868 y confirmada por la Constitución aprobada en junio de 1869, la primera constitución democrática de España, así como la sofisticación de los medios técnicos de imprenta dan lugar a la difusión y popularización de la alegoría femenina de España para plasmar los sinsabores de la vida política. El ejemplo gráfico más conocido se debe al genial caricaturista Tomás Padró, que ya había hecho sus primeras armas en la prensa satírica catalana a partir de 1865, y cuyo nombre va asociado al semanario satírico publicado en Barcelona a partir de marzo de 1869: La Flaca ${ }^{60}$. La pareja formada por la matrona y el león, ambos literalmente en los huesos, viene a encarnar las peripecias de la accidentada vida política de la época del Sexenio, a la vez que la «privatización» de la alegoría femenina, bajo forma de manola o de españolita de a pie (bajo el lápiz de Ortego), para representar a la nación española en la prensa ilustrada de la época, traduce en cierta forma que la política es asunto de todos y no es patrimonio de las élites gobernantes.

En la novela La tribuna, de Emilia Pardo Bazán, ambientada en el Sexenio Democrático, las obreras de la fábrica de tabacos se imaginan el enfrentamiento entre monarquía y república, tal como lo representa la prensa satírica de la época, bajo la forma de figuras femeninas: la primera «como una vieja carrancuda, arrugada como una pasa», con «manto de púrpura y

58. De la peseta al euro. 130 años de la historia de la moneda española. Madrid, Anderson Consulting, 1998, p. 19.

59. Sellos de España y dependencias postales. Catálogo especializado Madrid, edición Edifil S.A., 1990, p. 45

60. Esta publicación, de tendencia republicana federal, se prolonga hasta 1876, con diferentes títulos: La Carcajada, La Madeja política, La Madeja. 
estropeado», mientras que la República es «una moza sana, fornida, con túnica blanca, flamante gorro frigio $»^{61}$. El aire de libertad, la multiplicación de las revistas y publicaciones republicanas o de simpatías republicanas hace que se difunda en la prensa de la época la efigie republicana, trasunto de la Marianne francesa. En esta figura femenina, que encarna el ideal político de libertad, igualdad y fraternidad, se superponen el símbolo de la libertad y el emblema de la República. Sus atributos son invariablemente el gorro frigio, la balanza de platillos equilibrados, la toga romana que deja un pecho descubierto y a veces el gallo, por las razones aducidas anteriormente. De hierático porte es la Mariana sedente de perfil que sirve de portada a la

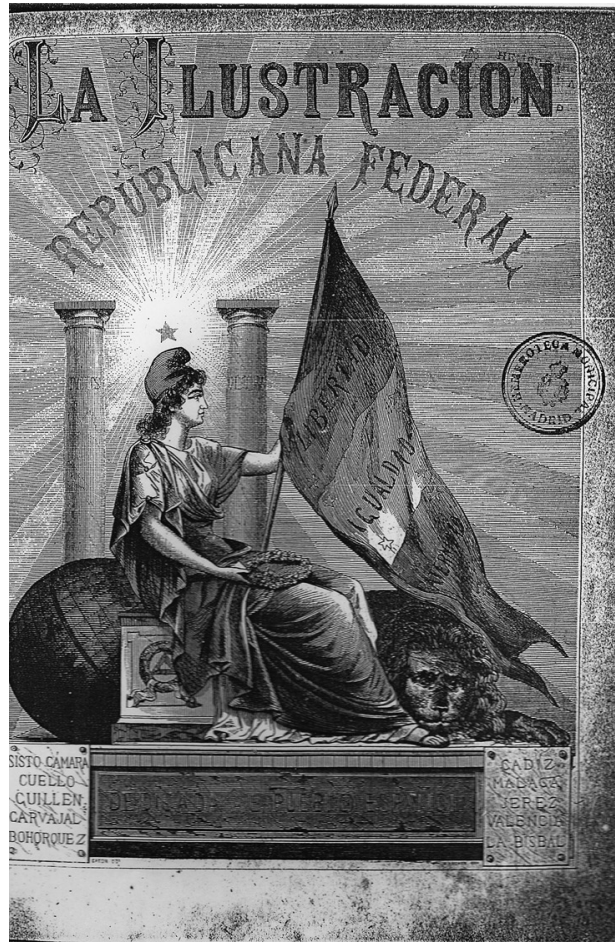

Figura 6 . colección de La Ilustración Republicana Federal, semanario creado por Enrique Rodríguez Solís, poco después de la caída de la Commune en París, en junio de $1871^{62}$ (Fig. 6). En este caso, la imagen funde la emblemática oficial española (las columnas de Hércules) con la simbología republicana: la figura femenina, acompañada del león -que en este caso es tanto símbolo republicano como emblema nacional- y tocada del gorro frigio enarbola la bandera tricolor que lleva inscrita la tríada republicana: igualdad, libertad y fraternidad. Sobre el zócalo además de la mención «Dedicada al pueblo español» se halla el triángulo masónico, símbolo de igualdad, mientras el globo terráqueo sobre el que reposa la efigie femenina,

61. PARdo BAZÁn, Emilia. La tribuna. Madrid, Cátedra, 1991 ( $1^{a}$ ed. 1883), p. 125.

62. El primer número, de 15-VI-1871, es un homenaje a la Commune que acaba de ser derrotada. La revista se publica semanalmente hasta el 16-IX-1872. Colaboraron en ella los líderes más destacados del republicanismo de aquella época: Francisco Pi y Margall, Emilio Castelar, Estanislao Figueras y Fernando Garrido. 
tomado prestado de la iconografía cristiana y de las alegorías de la monarquía, plasma la expansión universal de la idea republicana.

Pero la emblemática oficial, proclamada ya la República en España (el 11 de febrero de 1873), había de ser sensiblemente diferente de la iconografía propagandística difundida por la prensa republicana. Si bien La Gaceta de Madrid, después de recuperar a partir del 12 de febrero la efigie femenina, con pocas variaciones, que había servido para plasmar el nuevo régimen tras la caída de Isabel II, ostenta a partir del 3 de marzo una simbología marcadamente republicana (gorro frigio, haz revolucionario, nivel masónico) ${ }^{63}$, la comisión mixta formada por las Academias de la Historia y de Bellas Artes plantea desterrar de los soportes de la señas de identidad de la nación (escudo de armas, leyenda y atributos de la moneda) el gorro frigio, al que asocia en su informe con el terror y el desorden ${ }^{64}$. En cuanto a la alegoría femenina, la comisión propone una efigie, romana también, como lo hiciera el dictamen académico de noviembre de 1868, pero acudiendo esta vez a «la cabeza de Hispania» de tiempos del emperador Galba ${ }^{65}$. Mientras tanto, la prensa de adscripción republicana permanece fiel a la figura de Marianne tocada del gorro frigio, con el pecho o los pechos descubiertos, indudable símbolo de que la República es la madre nutricia. En efecto, el cuerpo femenino, a través de algunas especificidades morfológicas acentuadas, anchas caderas, pechos, es la traducción en carne del ideal republicano igualitario, popular y generoso. Es lo que da a entender una composición gráfica entre realidad y alegoría de Tomás Padró publicada en La Flaca en julio de 1873, en la que una Mariana, triunfalmente paseada en carro, tiene indudables aires de "La Marseillaise», que había esculpido François Rude para rendir homenaje a los voluntarios reclutados en 1792 para defender a Francia ${ }^{66}$. La figura femenina rodeada del pueblo, asimilada con él, es a la vez símbolo del poder de la idea republicana,

63. La cabecera del 3 de marzo de inconfundible sabor republicano se modifica levemente el 8 de abril (los elementos son los mismos, varía únicamente su colocación). Sorprendentemente se prolonga el uso de dicha composición alegórica hasta el 1 de mayo de 1874, es decir después del golpe del general Pavía.

64. A petición del gobierno del 16 de mayo de 1873, emite la comisión mixta formada para la ocasión su dictamen el 30 de julio de 1873, abordando dos puntos, la efigie y el escudo nacional. El dictamen se puede consultar en el Boletín de la Real Academia de la Historia, IV, 1884, pp. 192-198.

65. Ibíd., p. 197.

66. Se trata del altorrelieve que figura en uno de los pilares del célebre Arco del Triunfo parisino, inaugurado en 1836. En él, una mujer alada, el espíritu de la libertad, alienta al pueblo al combate. 
así como enseña y reivindicación de la unión en un contexto de crisis política con la amenaza de la insurrección cantonal ${ }^{67}$.

\section{Conclusión}

Si bien el cuerpo político-electoral de la nación a lo largo del siglo XIX es exclusivamente masculino, su traducción iconográfica y simbólica se encarna casi siempre en el cuerpo femenino. La gran estabilidad de la figura femenina, heredada de la monarquía, para encarnar la nación liberal y luego la democracia (a través de Hispania) hasta la república, se acompaña de una notable modificación de su morfología: la belleza femenina etérea de tiempos de la monarquía se carga de sensualidad con la democratización de la política.

Por otra parte, en el Sexenio, se multiplican en la prensa los grabados que representan a las mujeres, esta vez de carne y hueso, manifestándose, es decir en su actuación política e histórica. El movimiento de oposición a las quintas ve la implicación de las mujeres, es lo que refleja, por ejemplo, El Museo Universal, con un grabado que representa una manifestación de zaragozanas en enero de $1869^{68}$. El comentario que acompaña el grabado subraya el valor de estas mujeres, su condición de madres, su patriotismo y amor a la libertad, entremezclándose el papel tradicional de las mujeres y su compromiso político. Pero la creciente presencia de las mujeres en el espacio político de la manifestación y protesta, tal como se subraya en las ilustraciones de la prensa de la época del Sexenio, cobra, a mi parecer, un significado alegórico que supera el meramente histórico y testimonial. La figura femenina combativa viene a asimilarse con la fuerza popular en acción, con el poder del pueblo. En La Tribuna citada más arriba, Emilia Pardo Bazán elige a una joven obrera de una fábrica de tabacos, Amparo, como protagonista de su novela. Con ello se trataba de dar fe de la militancia femenina en una época determinada y, a la vez, de encarnar en este tribuno en femenino la creciente importancia del protagonismo popular durante el Sexenio. En efecto, «aquella buena moza», escribe la novelista, era «el viviente símbolo del pueblo joven ${ }^{69}$. Entre alegoría y realidad, el cuerpo femenino en su versión democratizada viene a ser la plasmación de las evoluciones políticas del siglo XIX.

67. La Flaca, 2-VII-1873. La leyenda de esta cromolitografía a doble página reza lo siguiente: «Solamente marchando unidos, podremos pasearla triunfante».

68. El Museo Universal, 31-I-1869. El dibujo es de Urrabieta. El Museo Universal cesa en noviembre de 1869, sucediéndole La Ilustración Española y Americana.

69. PARdo BAZÁn, Emilia. Op. cit., p. 152.

Feminismo/s 16, diciembre 2010, pp. 39-64 


\section{Referencias bibliográficas}

AGUlHON, Maurice. «La représentation de la France: quelques réflexions sur l'image féminine en politique». En M.-C. Hoock-Demarle (dir.). Femmes, Nations, Europe. París, Publications de l'Université Paris 7-Denis Diderot, 1995, pp. 12-17.

- Marianne au combat. París, Flammarion, 1979.

- y Bonte, Pierre. Marianne. Les visages de la République. París, Gallimard, 1992.

Alcalá Galiano, Antonio. Memorias de D. Antonio Alcalá Galiano, Edición digital a partir de Obras escogidas. Recuerdos y memorias. T. I, Madrid, Atlas, 1955.

Álvarez JunCO, José. Mater dolorosa. La idea de España en el siglo XIX. Madrid, Taurus, 2001.

BAECQue, Antoine de. Le corps de l'histoire. Métaphores et politique (1700-1800). París, Calmann-Lévy, 1993.

BARRIO MOYA, José Luis. "Aportaciones a la biografía del pintor valenciano José Ribelles y Elip (1775-1835)». Archivo de arte valenciano, 76 (1995), pp. 162-171.

Blom, Ida; Hagemann, Karen y Hall, Catherine (eds.). Gendered Nations. Nationalism and Gender Order in the Long Nineteenth Century. Oxford-New York, Oxford International Publishers, 2000.

Burdiel, Isabel (ed.). Monográfico La política en el reinado de Isabel II, Ayer, 29 (1998).

- Isabel II. No se puede reinar inocentemente. Madrid, Espasa Calpe, 2004.

Colección de grabados. Guerra de la Independencia 1808-1813. Catálogo de exposición, Álava, Museo de Armería de Álava, Diputación foral de Álava, 1997.

Cortes del barroco. Catálogo de exposición, Madrid, Sociedad Estatal para la Acción Cultural Exterior, 2003.

De la peseta al euro. 130 años de la historia de la moneda española. Madrid, Anderson Consulting, 1998.

DÉROZIER, Claudette. La Guerre d'Indépendance espagnole à travers l'estampe (18081814). París, Librairie Honoré Champion, 1976.

Estampas de la Guerra de la Independencia. Catálogo de exposición, Madrid, Ayuntamiento de Madrid, 1996.

FERnández SEbAstián, Javier. «El momento de la nación. Monarquía, Estado y nación en el lenguaje político del tránsito entre los siglos XVIII y XIX». En A. Morales Moya (coord.). 1802. España entre dos siglos Monarquía, Estado, Nación. Madrid, Sociedad Estatal de Conmemoraciones Culturales, 2003, pp. 55-78. 
FUENTES, Juan Francisco. «Iconografía de la idea de España en la segunda mitad del siglo XIX». Cercles d'Història cultural, Universitat de Barcelona, 5 (2002), pp. 8-25.

- «La matrona y el león: imágenes de la nación liberal en la España del Siglo XIX». Archivos de la filmoteca: Revista de estudios históricos sobre la imagen, 66 (2010), pp. 44-67.

GARCía Rovira, Ana María. «Radicalismo liberal, republicanismo y revolución (1835-1837)». Ayer, 29 (1998), pp. 63-90.

GUTIÉRREZ LlORET, Rosa Ana. «Da icona della libertà a disonore della Spagna: immagini della regina Isabella II nel processo di legittimazione sociale e politica della prima monarchia liberale spagnola (1830-1868)». En G. Guazzaloca (ed.). Sovrani a metà. Monarchia e legittimazione politica tra Otto e Novecento. Soveria Mannelli, Ed. Rubbetino, 2009, pp. 133-148.

Hernández GuARdiola, Lorenzo. «Un discípulo de la Academia de San Carlos: José Aparicio Inglada (1770-1838), pintor neoclásico español». Archivo de Arte Valenciano, 88 (2007), pp. 319-331.

Hunt, Lynn. Politics, Culture, and Class in the French Revolution. Berkeley-Los Angeles, University of California Press, 1984.

LA PARRA, Emilio. «El mito del rey deseado». En Sombras de mayo. Mitos y memorias de la Guerra de la Independencia en España (1808-1908). Madrid, Casa de Velázquez, 2007, pp. 221-236.

LARRAZ, Emmanuel. Théâtre et politique pendant la guerre d'indépendance espagnole: 1808-1814. Aix en Provence, Université de Provence, 1988.

LOCKE, John. Traité du Gouvernement civil. París, Flammarion, 2008.

MEnÉNDEZ PIDAL, Faustino. «Symbolique d'État et armoiries des Royaumes espagnols». En XVIII. Internationaler Kongre $\beta$ für Genealogie und Heraldik, 5-9 September 1988, Thaurdruck, Giesriegl Ges.m.b.H., Thaur/Tyrol, 1989, pp. 417-429.

MíNGUEZ, Víctor. «La iconografía del poder. Fernando VII y José I. Apoteosis y escarnio en la disputa del trono español». En A. Ramos Santana y A. Romero Ferrer (eds.). 1808-1812: los emblemas de la libertad. Cádiz, Servicio de publicaciones de la Universidad de Cádiz, 2009, pp. 163-189.

MORANGE, Claude. «La «Révolution espagnole» de 1808 à 1814. Histoire et écritures». En C. Morange, J.-R. Aymes, G. Brey, A. Lacour y A. Dérozier. La Révolution française et son "public» en Espagne entre 1808 et 1814. Annales Littéraires de l'Université de Besançon, Paris, Les Belles Lettres, 338 (1989), pp. 13-124.

Pastoureau, Michel. «Le coq gaulois». En P. Nora (dir.). Les lieux de mémoire, Les France. vol. III, París, Quarto Gallimard, 2004, pp. 4297-4319.

Pastoureau, Michel. Les emblèmes de la France. Paris, Éditions Bonneton, 1998.

Feminismo/s 16, diciembre 2010, pp. 39-64 
PORTILlo VAldÉS, José María. «Cuerpo de nación, pueblo soberano. La representación política en la crisis de la monarquía hispana». Ayer, 61 (2006), pp. 47-76.

REDONDO, Augustin (ed.). Le corps comme métaphore dans l'Espagne des XVI et XVII siècles. París, Presses de la Sorbonne Nouvelle, 1992.

REYero, Carlos. «Pintar a Isabel II: en busca de una imagen para la reina». En J.S. Pérez Garzón (ed.). Los espejos de la reina, Madrid, Marcial Pons Historia, 2004, pp. 231-246.

Roure, Conrad. Recuerdos de mi larga vida. Barcelona, El Diluvio, 1925.

Sellos de España y dependencias postales. Catálogo especializado, Madrid, edición Edifil S.A., 1990.

SIEYĖS, Emmanuel Joseph. Qu'est-ce que le tiers état?, préface de Jean-Denis Bredin, París, Flammarion, 1988. 